\title{
Sistem Layanan Informasi dan Pemesanan Nomor Antrian Menggunakan Media SMS Berbasis Komunikasi Serial Asinkron Multipoint Standar RS-485
}

\author{
Danny Kurnianto ${ }^{1}$, Panca Mudjirahardjo ${ }^{2}$, M. Julius $\mathrm{St}^{3}$ \\ ${ }^{1}$ Sekolah Tinggi Teknologi Telematika Telkom Purwokerto \\ ${ }^{2,3}$ Jurusan Teknik Elektro Universitas Brawijaya Malang \\ ${ }^{1}$ Jl. D.I. Panjaitan No. 128 Purwokerto, Banyumas, Jawa Tengah, Indonesia \\ 2,3 Jl. Mayjen Haryono 167 Malang \\ e-mail korespondensi : danny_kurnianto@yahoo.com
}

\begin{abstract}
Abstrak - Sistem layanan informasi dan pemesanan nomor antrian terpusat melalui media handphone dapat dijadikan sebagai salah satu solusi untuk mempermudah masyarakat dalam melakukan antrian sehingga aktivitas mereka bisa berjalan dengan baik dan waktu mereka tidak terbuang terlalu lama. Dengan menggunakan sistem ini, nasabah dapat dengan mudah melihat kondisi antrian saat ini dan memesan nomor antrian, yaitu dengan mengirimkan SMS berupa kata "daftar" untuk memesan nomor antrian dan kata "info" untuk mengetahui kondisi antrian ke handphone server. Personal komputer digunakan sebagai pusat pengendalian yang berfungsi untuk mengirim dan menerima data dari hanphone dan dari mikrokontroler pada unit slave. Komunikasi data antara komputer sentral dengan mikrokontroler berjalan dengan menggunakan komunikasi serial asinkron multipoint dengan baudrate 57600 bps. Komunikasi serial antara komputer sentral dengan handphone berjalan dengan baudrate 19200 bps. Dari hasil pengujian menunjukkan bahwa sistem layanan informasi dan pemesanan nomor antrian dapat bekerja dengan baik. Informasi yang diberikan saat nasabah mendaftar nomor antrian melalui handphone berupa nomor antrian dan password. Informasi yang diberikan komputer sentral saat nasabah meminta informasi kondisi antrian berupa berupa jumlah nasabah yang terdaftar pada sistem antrian saat ini, nomor antrian yang sedang dilayani pada masing-masing loket, waktu tutup antrian.
\end{abstract}

Kata kunci - Sistem antrian, layanan informasi antrian, pemesanan nomor antrian, komunikasi serial asinkron, standar RS485, media SMS.

\begin{abstract}
Centralized system for information service and reservation queue numbers through mobile devices can be used as a solution to facilitate the people to queue so that their activities can go well and their times not too long wasted. By using this system, customers can easily see the condition of the current queue and ordered queue numbers by sending an SMS to handphone server in the form of the word "daftar" to order the queue number and the word "info" to find out the condition of the queue. The personal computer was used as a control center that serves to send and receive data from a mobile phone and microcontroller on the slave units. The data communication between the central computer with the microcontroller running by using multipoint asynchronous serial communication with a baudrate of 57600 bps. Serial communication between the central computer with the mobile phone running with baudrate $19200 \mathrm{bps}$. From the test results show that the system of information services and reservation queue numbers can work well. Information provided when customers sign a queue number via mobile phones in the form of a queue number and password. The information provided by a central computer when the the customer requests information queuing conditions are the number of the customer registered on the system queue, the queue number being served at each counter, closing time queue.
\end{abstract}

Keywords- Queuing system, information service queue, reservation queue numbers, asynchronous serial communication, standar RS485, media SMS.

\section{PENDAHULUAN}

Masalah utama yang banyak terjadi pada layanan antrian umum seperti layanan antrian nasabah bank adalah aplikasi sistem antrian yang sudah diterapkan di beberapa bank masih belum efektif dan efisien karena tidak adanya fasilitas pengecekan kondisi antrian dan pemesanan nomor antrian secara mobile (jarak jauh). Tingginya tingkat aktifitas pekerjaan seseorang menyebabkan sedikitnya waktu yang tersedia untuk mengambil nomor antrian secara langsung di bank dan menunggu nomor antrian untuk di proses. Hal ini tentunya akan merugikan para nasabah yang sebagian besar dari mereka adalah para pekerja professional.

Beberapa penelitian yang pernah dilakukan untuk mengembangkan sistem antrian diantaranya seperti yang dikerjakan oleh Muhammad Haris dengan judul "Antrian Pada Loket Bank Berbasis IBM PC 
Kompatibel" [1]. Sistem antrian diatur oleh personal komputer dengan nasabah tidak perlu berdiri mengantri dan dapat melakukan aktivitas lainnya. Komunikasi data antara personal komputer dengan unit loket pelayanan dilakukan melalui antarmuka PPI 8255. Kelemahan sistem antrian yang dikembangkan oleh Muhammad Haris ini adalah tidak adanya fasilitas untuk mengetahui kondisi antrian dari jarak jauh. Yusuf Bahtiar mengusulkan sistem antrian untuk menutupi kelemahan dari sistem antrian yang dikembangkan oleh Muhammad Haris [2]. Sistem antrian tersebut selain mengatur pola antrian, nasabah juga dapat memberikan informasi antrian melalui telepon tetap PSTN sehingga nasabah dapat mengetahui informasi nomor urut antrian dan informasi antrian lainnya. Komunikasi data antara personal komputer sebagai pusat pengolah data dengan unit loket pelayanan menggunakan standar RS 485. Kelemahan dari sistem antrian yang diusulkan oleh Yusuf Bahtiar adalah tidak adanya fasilitas untuk melakukan pemesanan nomor antrian dari jarak jauh dan penggunaan telepon tetap PSTN sekarang ini sudah tidak efektif lagi.

Untuk memperbaiki kelemahan dari sistem antrian yang diusulkan oleh Yusuf Bahtiar, maka pada penelitian ini akan diusulkan suatu sistem antrian yang dikendalian oleh sebuah personal komputer dengan fasilitas pengecekan kondisi antrian dan pemesanan nomor antrian dari jarak jauh menggunakan fasilitas Short Message Service (SMS) pada sebuah ponsel. Komunikasi data antara personal komputer dengan unit loket pelayanan menggunakan standar RS 485 .

Makalah ini disusun sebagai berikut : BAB I menjelaskan pendahuluan, BAB II menjelaskan metodologi penelitian, BAB III menjelaskan hasil penelitian, BAB IV menjelaskan pembahasan penelitian, BAB V menjelaskan kesimpulan dan saran.

\section{METODOLOGI PENELITIAN}

\section{A. Diagram Blok Metodologi Penelitian}

Penelitian ini dilakukan berdasarkan metodologi ilmiah yang terdiri dari tahap studi literatur, perumusan masalah dan tujuan penelitian, merancangan dan pembuatan sistem, pengujian sistem, dan kesimpulan seperti yang ditunjukkan pada Gambar 1 .

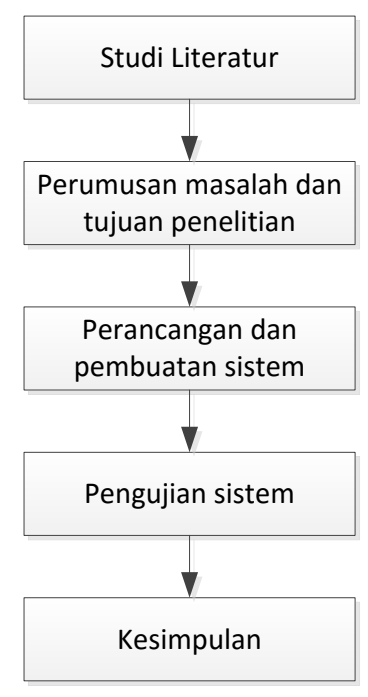

Gambar 1. Diagram blok metodologi penelitian

\section{B. Perancangan dan Pembuatan Sistem}

Sistem antrian yang diusulkan pada penelitian ini terdiri dari sebuah PC sebagai pusat pengendali, 2 unit loket pelayanan, 1 unit pendaftaran nomor antrian dan 1 unit penerima dan pengirim sms menggunakan ponsel seperti yang ditunjukkan pada Gambar 2.

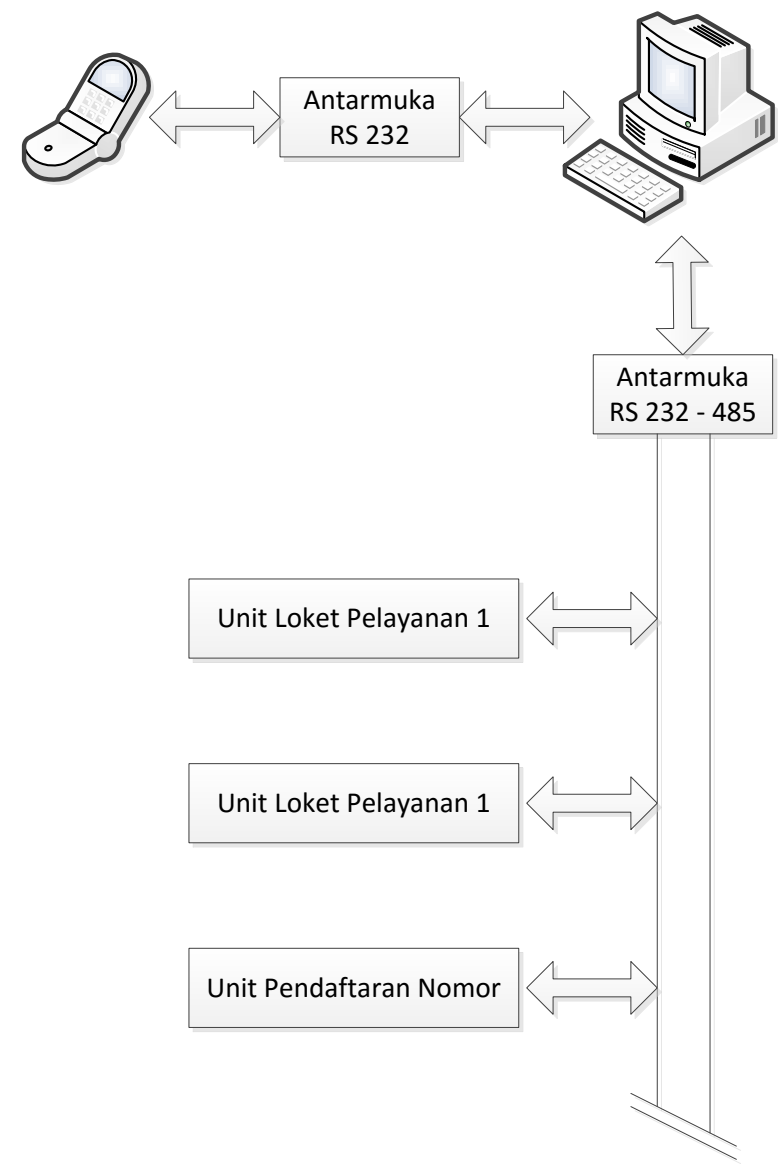

Gambar 2. Diagram blok sistem 


\section{Perangkat Keras Unit Pendaftaran Nomor}

Unit pendaftaran nomor terdiri dari sebuah mikrokontroler AT89S51, dua buah tombol sebagai tombol daftar nomor dan tombol daftar password, satu buah keypad 3x4 dan encoder 74C922, dua decoder 74LS47, dua buah display 7-segmen sebagai penampil display keluaran dan satu buah printer dot matrix seperti yang ditunjukkan pada Gambar 3. Unit ini berfungsi untuk mendata jumlah nasabah yang mengambil nomor antrian secara manual dan nasabah yang mengambil nomor antrian melalui media handphone dan akan ditampilkan di display 7-segmen. Penggunaan keypad pada unit ini untuk memasukkan password bagi nasabah yang memesan nomor antrian melalui handphone kemudian password tersebut akan dikirimkan ke komputer untuk mengecek kevalidannya, komputer akan memberitahukan nomor antrian password tersebut melalui pengeras suara. Nomor antrian yang telah dipesan oleh nasabah tersebut akan dicetak oleh printer sebagai tanda bukti bahwa nasabah tersebut telah terdaftar sebagai pengantri.

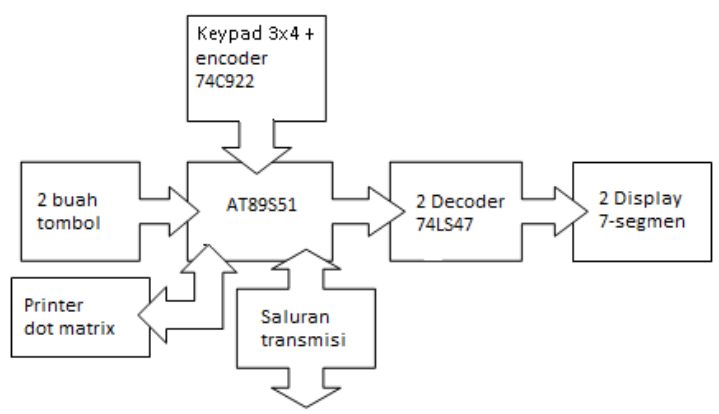

Gambar 3. Diagram blok unit pendaftaran nomor

1.) Rangkaian Mikrokontroler Unit Pendaftaran Nomor

Rangkaian mikrokontroler pada unit pendaftaran nomor seperti yang ditunjukkan pada Gambar 4. Pada perancangan ini digunakan osilator internal dengan menghubungkan pin XTAL1 dan pin XTAL2 pada dua buah kapasitor dan satu buah crystal seperti dalam Gambar 4. Nilai crystal yang digunakan sebesar $11.059 \mathrm{MHz}$ sehingga kecepatan pelaksanaan intruksi persiklus sebesar $1,085 \mu \mathrm{s}((1 / 11.059 \mathrm{MHz}) \times 12$ siklus perioda) dan nilai kapasitor yang digunakan sebesar $30 \mathrm{pF}$ sesuai datasheet mikrokontroler AT89S51 [7].

Untuk mereset mikrokontroler, maka pin RST harus diberi logika tinggi selama minimal 2 siklus mesin (24 periode osilator). Untuk membangkitkan sinyal reset diperlukan sebuah kapasitor bernilai $10 \mathrm{nF}$ dan sebuah resistor bernilai 8,2 $\mathrm{K} \Omega$.

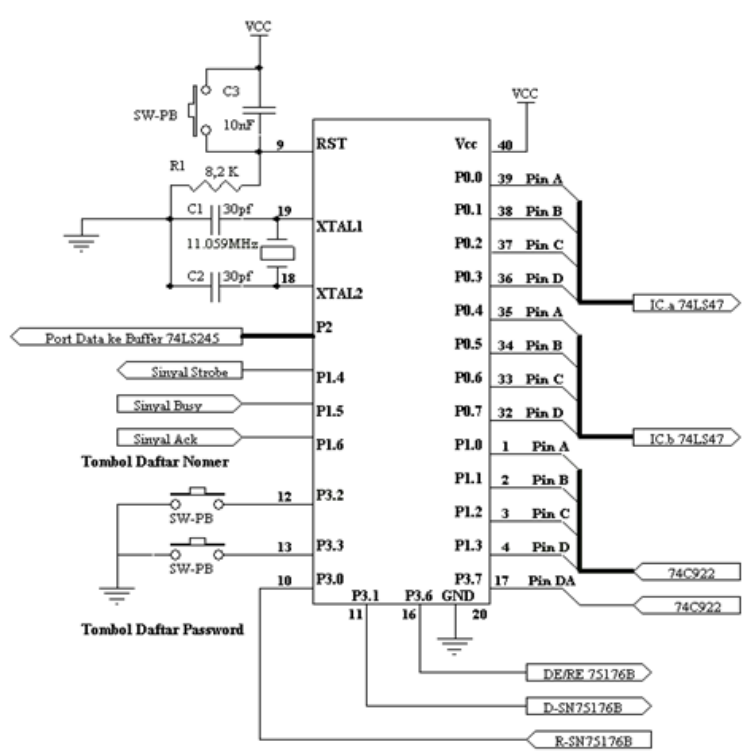

Gambar 4. Rangkaian mikrokontroler unit pendaftaran nomor

2.) Rangkaian Display 7 Segmen Pada Unit Pendaftaran Nomor

Untuk menampilkan data numerik digunakan display 7-segmen, dengan keluaran dua digit data numerik sehingga diperlukan dua buah display 7-segmen. Keluaran 8 bit mikrokontroler (P0.0-P0.7) dihubungkan dengan dua buah display 7-segmen melalui decoder 74LS47. Keluaran decoder 74LS47 berupa aktif rendah sehingga display 7-segmen yang digunakan adalah jenis common anode. Resistor pembatas arus yang digunakan sebesar $120 \Omega$. Pada Gambar 5 ditunjukkan rangkaian display 7-segmen.

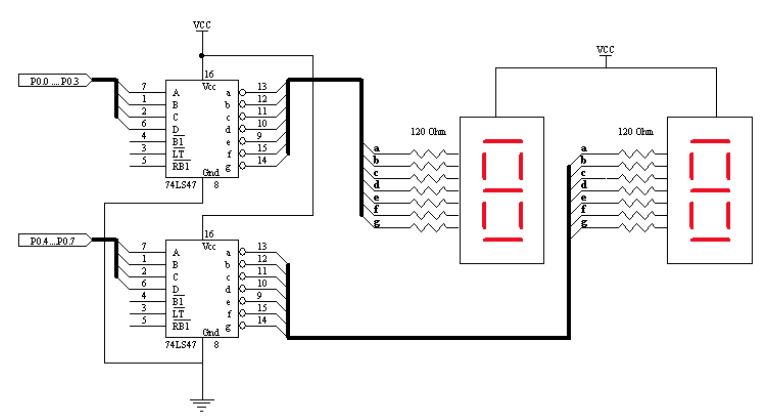

Gambar 5. Rangkaian display 7 segmen

3.) Rangkaian Antarmuka Standar RS 485 Pada Unit Pendaftaran Nomor

Rangkaian ini berfungsi untuk melakukan transmisi data antara personal komputer sebagai master dengan bagian unit loket pelayanan dan unit pendaftaran nomor sebagai slave. Komponen utama adalah IC SN75176B transceiver yang bertugas untuk mengubah level tegangan standar RS-485 menjadi level tegangan TTL pada mikrokontroler. Level logika TTL yang terjadi pada pin penerima (receiver) IC SN75176B sesuai dengan beda 
tegangan $\left(\mathrm{V}_{\mathrm{AB}}\right)$ yang terjadi pada bagian saluran komunikasi A dan B. Jika tegangan $\mathrm{V}_{\mathrm{AB}}$ lebih besar dari $200 \mathrm{mV}$ maka level logika ditetapkan pada keluaran receiver, artinya apabila tegangan input A lebih besar $200 \mathrm{mV}$ dari input $\mathrm{B}$ maka keluaran receiver akan berlogika 'high' dan apabila tegangan B lebih besar $200 \mathrm{mV}$ dari A maka keluaran receiver akan berlogika 'low' [8-9]. Pada Gambar 6 ditunjukkan rangkaian komunikasi RS-485.

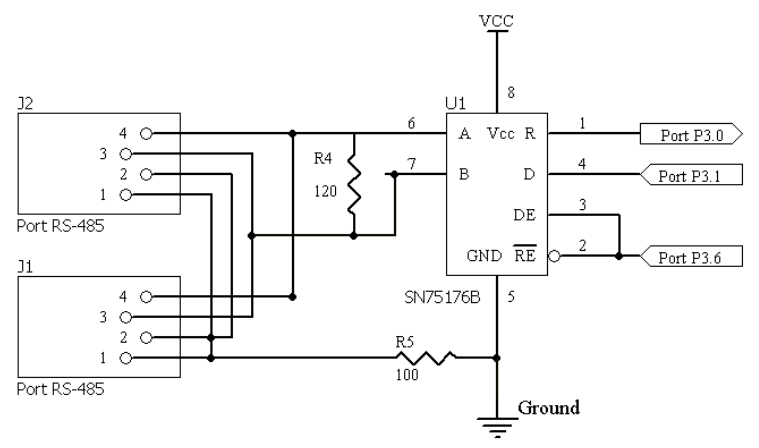

Gambar 6. Rangkaian antarmuka RS 485

Pada komunikasi multipoint standar RS485, diperlukan dua buah resistor terminasi sebesar $120 \Omega$ yang dipasang pada kedua ujung saluran transmisi yang berfungsi untuk menjaga agar karakteristik impedansi saluran transmisi tetap matching sehingga tidak terjadi gejala pemantulan sinyal pada saluran tarnsmisi. Sebuah resistor sebesar $100 \Omega$ dipasang secara seri pada saluran yang terhubung pada ground setiap unit untuk mencegah terjadinya arus yang tidak diinginkan karena perbedaan potensial ground pada masing-masing unit [8-9].

4.) Rangkaian Pengkode Papan Tombol Pada Unit Pendaftaran Nomor

Rangkaian ini berfungsi untuk mengubah kode numerik pada keypad menjadi kode biner 4 bit yang akan di proses oleh mikrokontroler. Komponen utama bagian ini adalah sebuah keypad 4x3 dan sebuah encoder 74C922 yang memiliki keluaran empat bit. Pada Gambar 7 ditunjukkan rangkaian pengkode papan tombol.

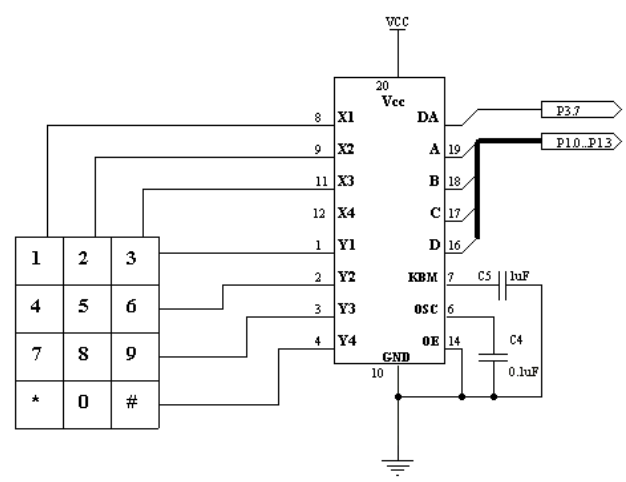

Gambar 7. Rangkaian pengkode papan tombol
Besarnya nilai kapasitor osilator $\left(\mathrm{C}_{4}\right)$ dan kapasitor keybounce mask $\left(\mathrm{C}_{5}\right)$ ditentukan dari persamaan $\mathrm{T}_{1} \approx \mathrm{T}_{2} \approx \mathrm{RC}$, dimana nilai $\mathrm{R}$ sebesar $10 \mathrm{~K} \Omega$ dan $\mathrm{C}$ merupakan kapasitor keybounce mask $\left(\mathrm{C}_{5}\right)$. Besarnya kapasitor osilator $\left(\mathrm{C}_{4}\right)$ adalah sepersepuluh dari kapasitor keybounce mask $\left(\mathrm{C}_{5}\right)$ [3].

5.) Rangkaian Antarmuka Printer Dot Matrix

Rangkaian ini berfungsi untuk mencetak nomor antrian nasabah yang sudah terdaftar sebagai pengantri. Komponen utama pada rangkaian ini adalah sebuah printer (dot matrix) dan sebuah buffer 74LS245. Antarmuka dengan printer dilakukan secara paralel menggunakan konektor DB-25 yang dihubungkan dengan port mikrokontroler. Tidak semua pin-pin dari printer terhubung dengan mikrokontroler, dipilih pin-pin tertentu yang sangat penting dalam proses pengiriman data ke printer. Pin-pin tersebut adalah 8 pin data dan 3 pin masing-masing untuk Strobe, Busy dan Acknowledge. Delapan pin data dihubungkan dengan dengan port $\mathrm{B}$, sedangkan sinyal Strobe, Busy dan Ack masing-masing terhubung dengan port P1.4, port P1.5 dan port P1.6 mikrokontroler. Untuk mempertegas logika keluaran port P2 ke bus data printer maka perlu dipasang buffer menggunakan IC 74LS245. Pada Gambar 8 ditunjukkan rangkaian antarmuka printer dot matrix.

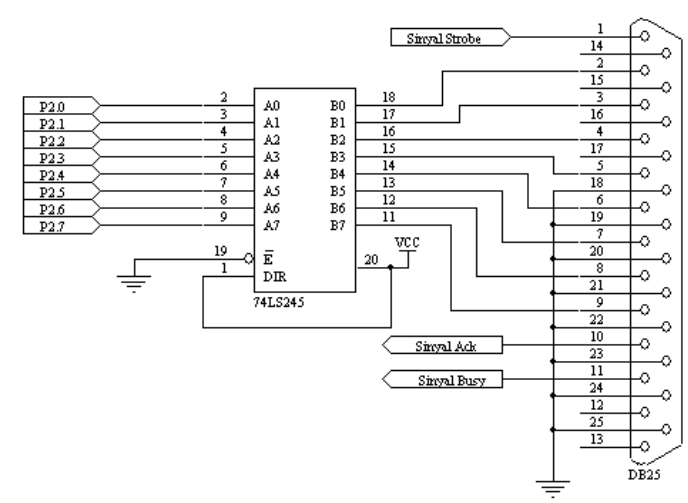

Gambar 8. Rangkaian antarmuka printer dot matrix

\section{Perangkat Keras Unit Loket Pelayanan}

Unit ini terdiri dari satu mikrokontroler AT89S51 sebagai komponen utama, dua buah tombol sebagai tombol tunda dan tombol selesai transaksi, dua buah decoder 74LS47 dan dua buah display 7-segmen seperti yang ditunjukkan pada Gambar 9. Unit ini berfungsi untuk melayani transaksi nasabah dengan menampilkan data nomor antrian nasabah yang akan dikirim oleh komputer sentral kemudian akan ditampilkan pada dua buah display 7-segmen. 


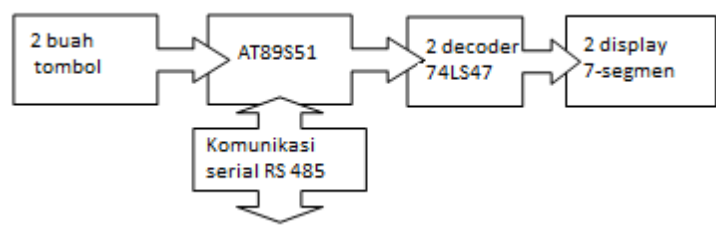

Gambar 9. Diagram blok unit loket pelayanan

1.) Rangkaian Mikrokontroler Unit Loket Pelayanan

Pada dasarnya, rangkaian mikrokontroler AT89S51 pada unit loket pelayanan adalah sama dengan unit pendaftaran nomor, bedanya adalah pada unit ini tidak terhubung pada printer dot matrix dan keypad. Pada Gambar 10 ditunjukkan rangkaian mikrokontroler AT89S51 pada unit loket pelayanan.

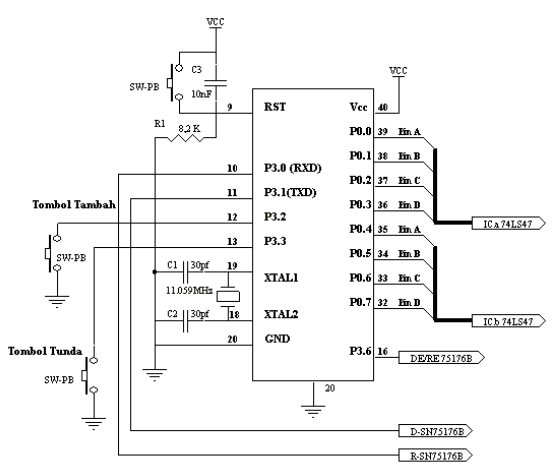

Gambar 10. Rangkaian mikrokontroler AT89S51 pada unit loket pelayanan

2.) Rangkaian Display 7 Segmen Pada Unit Loket Pelayanan

Untuk menampilkan 2 digit angka numerik, maka dibutuhkan 2 buah display 7-segmen sehingga rangkaiannya sama dengan rangkaian display 7-segmen pada unit pendaftaran nomor seperti yang ditujukkan pada Gambar 5.

3.) Rangkaian Antarmuka Standar RS 485 Pada Unit Loket Pelayanan

Rangkaian standar RS-485 pada unit ini pada dasarnya sama dengan rangkaian pada unit pendaftran nomor, tetapi pada unit ini tidak diberi resistor terminasi karena letak unit ini tidak pada ujung saluran transmisi. Pada Gambar 11 ditunjukkan rangkaian antarmuka RS 485 pada unit loket pelayanan.

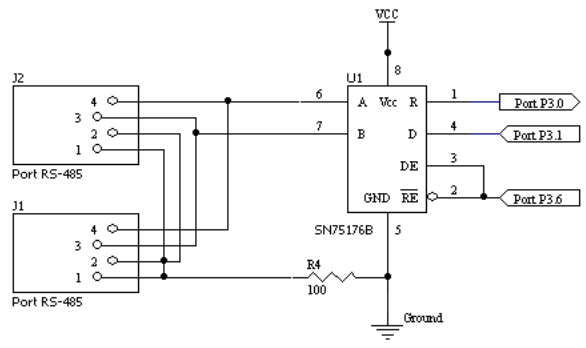

Gambar 11. Rangkaian antarmuka RS 485 pada unit loket pelayanan
4.) Rangkaian Antarmuka RS 232 ke RS 485

Level tegangan logika pada port serial komputer merujuk pada Electronic Industry Association (EIA) standar RS232 yaitu untuk level logika "1" (tinggi) berada pada kisaran tegangan $-3 \mathrm{~V}$ hingga $-25 \mathrm{~V}$, logika "0" berada pada kisaran tegangan $+3 \mathrm{~V}$ hingga +25 $\mathrm{V}$. Daerah antara tegangan $+3 \mathrm{~V}$ hingga $-3 \mathrm{~V}$ tidak terdefinisikan atau tidak terpakai [4]. Sehingga untuk melakukan komunikasi serial multipoint dengan perangkat yang menggunakan level logika TTL maka level logika port serial komputer harus di konversi ke level logika TTL ataupun sebaliknya dengan menggunakan IC MAX232 dan IC 75176B seperti yang ditunjukkan pada Gambar 12.

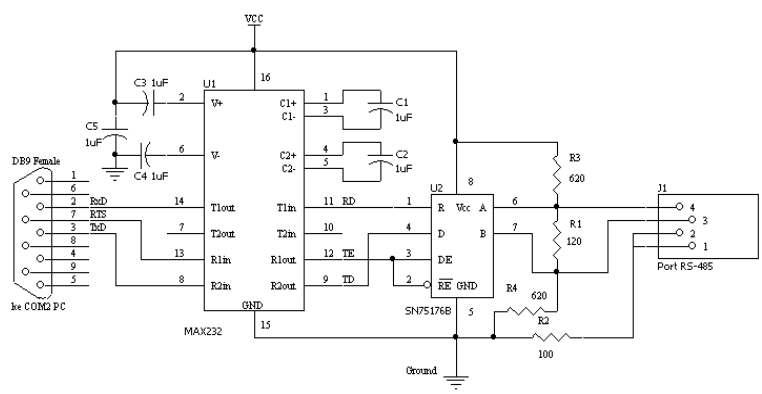

Gambar 12. Rangkaian antarmuka RS232 ke RS485

Besarnya nilai kapasitor $\mathrm{C}_{1}$ sampai $\mathrm{C}_{5}$ adalah $1 \mu \mathrm{F}$ berdasarkan petunjuk pemakaian IC MAX232 [5]. Level tegangan TTL keluaran IC MAX232 akan dikonversi ke level tegangan RS-485 menggunakan IC SN75176B. Saluran transmisi RS-485 bagian ini menggunakan rangakaian fail-safe biasing dengan nilai resistor sebesar $620 \Omega$ agar dihasilkan tegangan $\geq 200 \mathrm{mV}$ pada saat saluran transmisi dalam keadaan idle.

\section{E. Antarmuka Handphone Dengan Personal Komputer}

Personal komputer sebagai pusat pengendali menerima data dari handphone yang berupa data permintaan informasi antrian dan data permintaan pendaftaran nomor antrian. Handphone yang digunakan adalah Siemen C35 dengan komunikasi serial pada baudrate sebesar 19200 bps [6]. Pada Gambar 13 ditunjukkan antarmuka handphone dengan personal komputer.

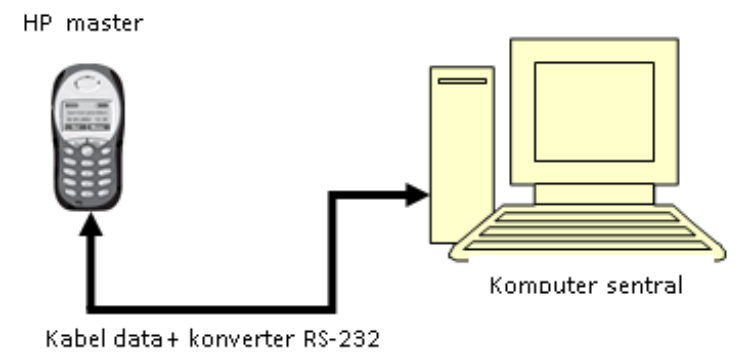

Gambar 13. Antarmuka handphone dengan PC 
Untuk permintaan informasi antrian digunakan kode karakter "info" dan untuk permintaan pendaftaran nomor antrian digunakan kode karakter "daftar". Nasabah tinggal mengirim sms dengan pesan "info" atau "daftar" ke nomor handphone sentral.

\section{F. Protokol Komunikasi Data Antara Personal Komputer Dengan Mikrokontroler}

Komunikasi serial asinkron multipoint yang menggunakan standar RS-485 antara komputer sentral sebagai master dengan unit-unit slave (mikrokontroler) diperlukan suatu format komunikasi atau protokol komunikasi yang baik dan terstruktur agar komunikasi serial dapat berjalan dengan baik. Pengiriman data serial antara komputer sentral dengan mikrokontroler atau sebaliknya menggunakan format protokol data serial. Pada Gambar 14 ditunjukkan format protokol data serial.

\begin{tabular}{|c|c|c|c|}
\hline Kode Alamat & Paket Data & Check Error & Kode Stop \\
\hline
\end{tabular}

Gambar 14. Protokol komunikasi data serial

Keterangan :

Kode Alamat : berisi kode tertentu sebesar 1 Byte yang merupakan alamat unit-unit MCU dan merupakan awal blok data.

Paket Data : berisi data maksimal 4 Byte yang berupa; minta status, kondisi status, data nomor antrian, data password, pesan error.

Check Error : berisi nilai validitas data sebesar 1 Byte berupa hasil operasi OR dari awal data sampai akhir paket data.

Kode Stop : berisi kode sebesar 1 Byte sebagai tanda akhir data yang dikirim atau diterima.

Pada Tabel 1 ditunjukkan kode hexa protokol komunikasi pada komputer sentral. Sedangkan pada Tabel 2 ditunjukkan kode hexa protokol komunikasi pada mikrokontroler.

Tabel 1. Kode hexa protokol komunikasi pada komputer sentral

\begin{tabular}{|c|l|l|}
\hline \multicolumn{1}{|c|}{ JENIS } & \multicolumn{1}{|c|}{ DEFINISI } & BYTE \\
\hline Kode Alamat & $\begin{array}{l}\text { A= kode alamat unit } \\
\text { pendaftarannomor }\end{array}$ & 1 Byte \\
& B=kode alamat unit & 1 Byte \\
& pelayananloket 1 & 1 Byte \\
& C=kode alamat unit & \\
& pelayananloket 2 & \\
\hline Paket Data & = = minta status unit slave & 1 Byte \\
& s= writepassword & 1 Byte \\
& Nomor antrian & 2 Byte \\
\hline Kode Stop & Q = tanda akhir data & 1 Byte \\
\hline
\end{tabular}

Tabel 2. Kode hexa protokol komunikasi pada mikrokontroler

\begin{tabular}{|c|c|c|}
\hline JENIS & DEFINISI & BYTE \\
\hline Kode Alamat & $\begin{array}{l}\mathrm{A}=\text { kode alamat unit } \\
\text { pendaftarannomor } \\
\mathrm{B}=\text { kode alamat unit } \\
\text { pelayananloket } 1 \\
\mathrm{C}=\text { kode alamat unit } \\
\text { pelayananloket } 2\end{array}$ & $\begin{array}{l}1 \text { Byte } \\
1 \text { Byte } \\
1 \text { Byte }\end{array}$ \\
\hline Paket Data & $\begin{array}{l}\mathrm{T}=\text { tambah nomor antrian } \\
\mathrm{U}=\text { tunda nomor antrian } \\
\mathrm{S}=\text { unit sedang sibuk } \\
\mathrm{N}=\text { tambah pengantrian } \\
\mathrm{P}=\text { entry pas sword } \\
\mathrm{E}=\text { pesan error } \\
\text { Pas sword }\end{array}$ & $\begin{array}{l}1 \text { Byte } \\
1 \text { Byte } \\
1 \text { Byte } \\
1 \text { Byte } \\
1 \text { Byte } \\
1 \text { Byte } \\
3 \text { Byte }\end{array}$ \\
\hline Kode Stop & Q = tanda akhir dari data & 1 Byte \\
\hline
\end{tabular}

Metode yang digunakan komputer sentral untuk berkomunikasi dengan unit-unit slave (mikrokontroler) adalah metode polling half-duplex dimana komunikasi terjadi secara dua arah bergantian dan komputer sentral yang menentukan unit-unit slave (mikrokontroler) mana yang boleh berkomunikasi saat itu.

\section{HASIL DAN PEMBAHASAN}

Pengujian sistem dilakukan secara bertahap, kemudian setelah itu baru dilakukan pengujian sistem secara keseluruhan.

\section{A. Pengujian Display 7-Segmen}

Pengujian terhadap display 7-segmen dilakukan untuk mengetahui apakah rangkaian display 7-segmen dapat berfungsi dengan baik yaitu menampilkan data numerik berdasarkan bilangan biner yang diberikan pada input IC SN74LS47. Pada Tabel 3 ditunjukkan hasil pengujian display 7-segmen. 
Tabel 3. Hasil pengujian display 7-segmen

\begin{tabular}{|c|c|c|c|c|c|c|c|c|c|c|c|}
\hline \multicolumn{4}{|c|}{ Input Logic } & \multicolumn{7}{|c|}{ Keluaran } & \multirow{3}{*}{ Angk: } \\
\hline \multirow{2}{*}{ D } & \multirow{2}{*}{ C } & \multirow{2}{*}{ B } & \multirow{2}{*}{$\mathbf{A}$} & $\mathbf{a}$ & b & c & d & e & f & g & \\
\hline & & & & state & state & state & state & state & state & state & \\
\hline 0 & 0 & 0 & 0 & ON & ON & ON & ON & ON & ON & OFF & 0 \\
\hline 0 & 0 & 0 & 1 & OFF & ON & ON & OFF & OFF & OFF & OFF & 1 \\
\hline 0 & 0 & 1 & 0 & ON & ON & OFF & ON & ON & OFF & ON & 2 \\
\hline 0 & 0 & 1 & 1 & ON & ON & $\mathrm{ON}$ & ON & OFF & OFF & ON & 3 \\
\hline 0 & 1 & 0 & 0 & OFF & ON & ON & OFF & OFF & ON & ON & 4 \\
\hline 0 & 1 & 0 & 1 & ON & OFF & ON & ON & OFF & ON & ON & 5 \\
\hline 0 & 1 & 1 & 0 & OFF & OFF & ON & ON & ON & ON & ON & 6 \\
\hline 0 & 1 & 1 & 1 & ON & ON & ON & OFF & OFF & OFF & OFF & 7 \\
\hline 1 & 0 & 0 & 0 & ON & ON & ON & ON & ON & ON & ON & 8 \\
\hline 1 & 0 & 0 & 1 & ON & ON & ON & OFF & OFF & ON & ON & 9 \\
\hline
\end{tabular}

Tabel 4. Hasil pengujian papan tombol (keypad)

\begin{tabular}{|c|c|c|c|c|c|}
\hline \multirow{2}{*}{$\begin{array}{c}\text { Tombol yang } \\
\text { ditekan }\end{array}$} & \multicolumn{5}{|c|}{ Keluaran } \\
\cline { 2 - 6 } & D & C & B & A & DA \\
\hline 0 & 1 & 1 & 0 & 1 & 1 \\
\hline 1 & 0 & 0 & 1 & 0 & 1 \\
\hline 2 & 0 & 0 & 0 & 1 & 1 \\
\hline 3 & 0 & 0 & 0 & 0 & 1 \\
\hline 4 & 0 & 1 & 1 & 0 & 1 \\
\hline 5 & 0 & 1 & 0 & 1 & 1 \\
\hline 6 & 0 & 1 & 0 & 0 & 1 \\
\hline 7 & 1 & 0 & 1 & 0 & 1 \\
\hline 8 & 1 & 0 & 0 & 1 & 1 \\
\hline 9 & 1 & 0 & 0 & 0 & 1 \\
\hline$*$ & 1 & 1 & 0 & 0 & 1 \\
\hline$\#$ & 1 & & 1 & 0 & 1 \\
\hline
\end{tabular}

Dari hasil pengujian terhadap display 7-segmen seperti yang ditunjukkan pada Tabel 3, rangkaian display 7-segmen dapat berkerja dengan baik sesuai dengan yang telah direncanakan yaitu dapat menampilkan data numerik dari nilai 0 sampai 9 pada keluaran yang sesuai dengan data input logic, bilangan numerik bertambah 1 dengan ditekannya tombol interupsi.

\section{B. Pengujian Papan Tombol (Keypad)}

Pengujian pada papan tombol $4 \times 3$ untuk mengetahui apakah papan tombol dan IC encoder 74C922 bekerja dengan baik yaitu dapat menampilkan data keluaran dalam bentuk biner yang mewakili setiap tombol pada papan tombol. Pada Tabel 4 ditunjukkan hasil pengujian rangkaian papan tombol (keypad).

Dari hasil pengujian terhadap papan tombol $4 \times 3$ dan IC encoder 74C922 maka didapatkan bahwa rangkaian tersebut dapat bekerja dengan baik dengan diperoleh data biner pada keluaran yang bersesuian dengan karakter masing-masing tombol.

\section{Pengujian Antarmuka Handphone Dengan Komputer}

Pengujian antarmuka handphone dengan komputer bertujuan untuk mengetahui apakah handphone dapat berkomunikasi secara baik dengan komputer. Pengujian ini dilakukan dengan mengirimkan perintah AT-Command dari komputer ke handphone dan mengamati dan memproses respon yang diberikan oleh handphone. Perintah AT-Command yang diujikan adalah AT + CMGS dan AT + CMGL.

AT+CMGS adalah perintah ini digunakan untuk mengirimkan SMS dalam bentuk PDU (Protocol Data Unit). AT+CMGL adalah perintah ini digunakan untuk mengetahui daftar SMS yang terdapat di memori SIM card [6]. 
Pada Gambar 14 ditunjukkan hasil pengujian perintah AT+CMGL, Handphone memberikan respon berupa sms lama yang terdapat pada inbox SIM CARD dalam bentuk PDU. Sedangkan pada Gambar 15 ditunjukkan hasil pengujian perintah AT+CMGS. Handphone memberikan respon "OK" jika sms sudah terkirim ke tujuan.

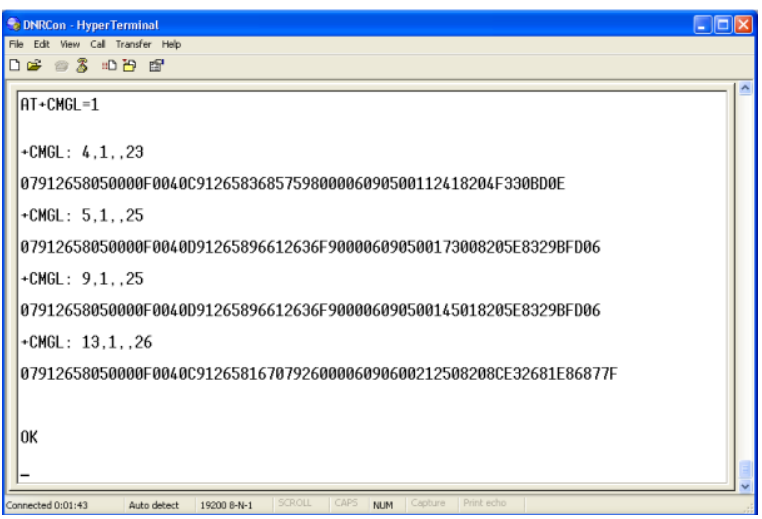

Gambar 14. Hasil pengujian perintah AT+CMGL

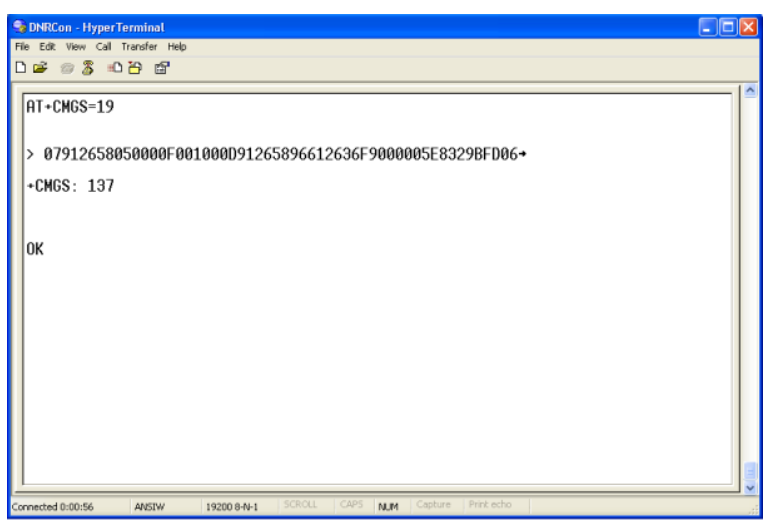

Gambar 15. Hasil pengujian perintah AT+CMGS

\section{Pengujian Komunikasi Serial Antara Komputer Dengan Mikrokontroler}

Pengujian komunikasi serial antara komputer dengan mikrokontroler dilakukan untuk mengetahui apakah data yang dikirimkan oleh komputer dapat diterima dengan baik pada mikrokontroler yang ditampilkan oleh peraga LED 8 bit ?, dan apakah mikrokontroler dapat mengirimkan kembali data tersebut ke komputer ?. Pada pengujian ini komunikasi serial bekerja pada boudrate 9600 bit/sekon. Data yang akan di kirim ke mikrokontroler di akhiri dengan huruf "Q", jika komunikasi berjalan dengan baik maka komputer akan menerima respon berupa data yang dikirim di ikuti dengan "DATA OK". Pada Gambar 16 ditunjukkan hasil pengujian komunikasi serial antara komputer dengan mikrokontroler.
PROGRAM PENGUJIAN KOMUNIKASI SERIAL BOUDRATE 9600 BPS

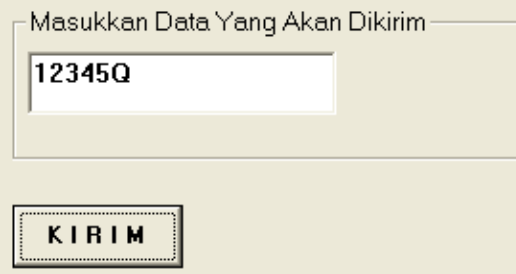

RESPON DARI MIKROKONTROLER

12345 DATA OK

BY DANNYK

Gambar 16. Hasil pengujian komunikasi serial antara komputer dengan mikrokontroler

Berdasarkan hasil pengujian pada Gambar 16, maka komunikasi data berjalan dengan baik, komputer dapat mengirimkan data ke mikrokontroler dan juga menerima data respon dari mikrokontroler. Demikian juga sebaliknya, mikrokontroler dapat mengirim data ke komputer dan menerima data dari komputer yang ditampilkan di peraga LED.

\section{E. Pengujian Sistem Secara Keseluruhan}

Untuk mengetahui kinerja sistem secara keseluruhan berdasarkan perancangan yang telah dibuat, maka dilakukan pengujian terhadap seluruh sistem sesuai dengan diagram blok sistem pada Gambar 2. Pada Gambar 17 ditunjukkan hasil pengujian software antarmuka user untuk unit pendaftaran nomor dan unit loket pelayanan.

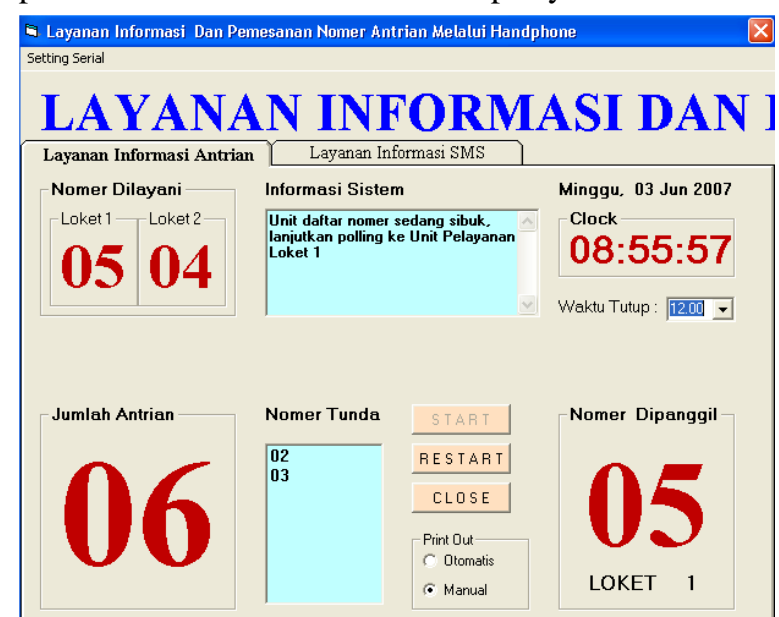

Gambar 17. Hasil pengujian software antarmuka user untuk unit pendaftaran nomor dan unit loket pelayanan

Pada saat tombol daftar pada unit pendaftaran nomor ditekan, maka nomor antrian akan bertambah yang ditunjukkan display-7 segmen pada unit 
pendaftaran nomor dan software antarmuka user, jika print out di setting secara otomatis maka nomor antrian nasabah akan dicetak melalui printer. Ketika tombol entry password ditekan maka unit pendaftaran nomor akan mengirimkan nomor password ke komputer sentral sesuai dengan tombol yang ditekan pada keypad, kemudian dicocokkan apakah password tersebut ada pada database software utama atau tidak.

Pada saat unit loket pelayanan meminta tambah nomor antrian maka software antarmuka user mengirimkan nomor antrian yang akan dilayani pada unit loket pelayanan dengan menampilkannya pada display-7segmen dan melakukan panggilan nomor antrian tersebut. Pada saat unit loket pelayanan meminta tunda nomor antrian maka software antarmuka user akan menunda nomor antrian yang sedang dilayani, mengirimkan nomor antrian berikutnya ke unit loket pelayanan dengan menampilkannya pada display-7segmen dan melakukan panggilan nomor antrian tersebut.

Pada Gambar 18 ditunjukkan hasil pengujian software antarmuka user untuk pendaftaran nomor antrian dan meminta layanan informasi antrian melalui handphone (SMS).

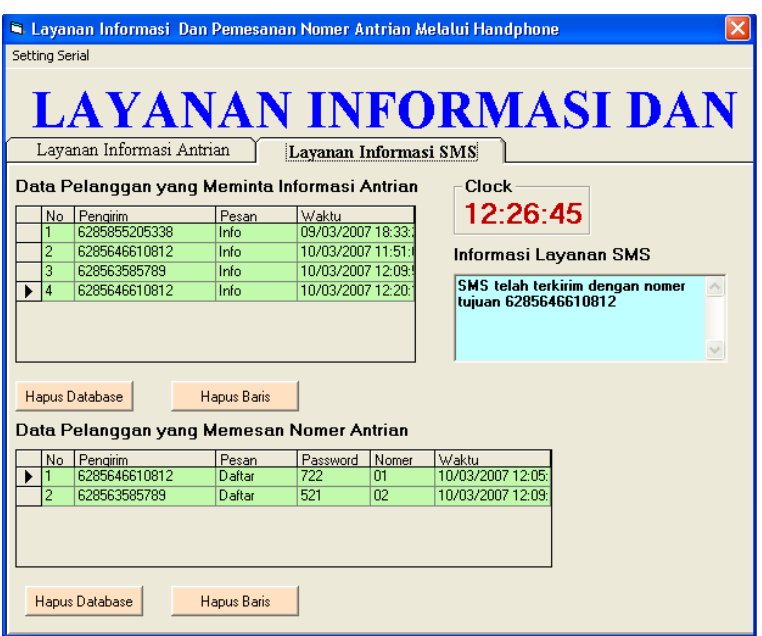

Gambar 18. Hasil pengujian software antarmuka user untuk pendaftaran nomor dan layanan informasi antrian melalui media SMS

Pada saat nasabah mengirimkan SMS berupa kata "daftar" ke handphone server maka software antarmuka user akan memberikan nomor antrian kepada nasabah tersebut dengan disertai password untuk pengambilan nomor secara langsung. Pada saat nasabah mengirimkan SMS berupa kata "info" ke handphone server maka software antarmuka user akan memberikan informasi antrian berupa jumlah antrian saat ini, nomor antrian yang sedang dilayani pada masing-masing loket, dan waktu tutup layanan antrian.

\section{PENUTUP}

\section{A. Kesimpulan}

Pada penelitian ini, dapat diambil kesimpulan sebagai berikut.

1. Komunikasi data antara handphone Siemens C35 dengan komputer dapat dilakukan dengan menggunakan boudrate sebesar 19200 bps.

2. Komunikasi data antara unit slave (mikrokontroler) dengan komputer sebagai master bekerja pada boudrate 57600 bps, dengan komunikasi serial asinkron secara haft duplex.

3. Layanan informasi dan pemesanan nomor antrian melalui handphone (SMS) dilakukan dengan mengirimkan kata "daftar" untuk memesan nomor antrian dan kata "info" untuk meminta informasi kondisi antrian.

4. Informasi yang dikirim ke nasabah melalui sms berupa nomor antrian dan password jika nasabah memesan nomor antrian melalui handphone. Informasi yang dikirim ke nasabah melalui sms berupa jumlah pengantri saat ini, nomor antrian yang sedang dilayani pada masing-masing loket, waktu tutup antrian jika nasabah meminta informasi kondisi antrian melalui handphone.

\section{B. Saran}

Untuk pengembangan alat ini selanjutnya, diharapkan bisa menggunakan fasilitas lainnya pada handphone untuk berkomunikasi dengan komputer, misalnya menggunakan inframerah, Bluetooth, aplikasi android dan sebagainya.

\section{DAFTAR PUSTAKA}

[1] M. Haris, “Antrian Pada Loket Bank Berbasis IBM PC Kompatibel,” Universitas Brawijaya, 2002.

[2] Y. Bahtiar, "Sistem antrian multiloket yang termonitor melalui saluran telepon," Universitas Brawijaya, 2004.

[3] Datasheet, "MM74C922-MM74C923-16 Key Encoder-20 Key Encoder," Fairchild Semiconductor Corporation, 1999.

[4] W. Budiharto, Interfacing Komputer dan Mikrokontroller. Jakarta: PT Elex Media Komputindo, 2004.

[5] Datasheet, +5V-Powered, Multichannel RS-232, Drivers/Receivers. MAXIM.

[6] B. Khang, Trik Pemrograman Aplikasi Berbasis SMS. Jakarta: PT. Elex Media Komputindo, 2002.

[7] ATMEL. "8 Bit Microcontroller With 4K Byte In-System Programmable Flash AT89S51”. ATMEL Corp. 2001.

[8] B \& B Electronics, "RS-422 and RS-485 Aplication Note," 1992.

[9] Soltero, Manny dkk, "422 and 485 Standars Overview and System Configurations," Texas Instruments, 2000. 
